\title{
The Stratification of Organic Carbon and Nitrogen in Top Soils as Affected by the Management of Organic and Conventional Rice Cultivation
}

\author{
Arif Anshori' ${ }^{1 *}$, Ali Pramono² and Mujiyo ${ }^{3}$ \\ ${ }^{1}$ Assessment Institute for Agricultural Technology of Yogyakarta, Yogyakarta, Indonesia; ${ }^{2}$ Indonesian \\ Agricultural Environment Research Institute, Pati, Indonesia; ${ }^{3}$ Department of Soil Science, Faculty \\ of Agriculture, Universitas Sebelas Maret, Surakarta, Indonesia \\ ${ }^{*}$ Corresponding author: arifanshori@yahoo.com
}

\begin{abstract}
Organic and conventional management in rice cultivation have an impact on the nature of soil and the sustainability of agricultural system. This study aimed to determine the stratification of organic carbon and nitrogen in top soil from organic and conventional rice management. Top soil samples from organic and conventional rice management were taken before planting rice to find out the parameters of several soil characteristics. After rice was planted, top soil samples were taken at the depths of $0-4,4-8,8-12$, $12-16,16-20,20-24$ and $24-28 \mathrm{~cm}$ from organic and conventional rice fields, to determine the total organic carbon, total nitrogen and nitrate. The results show that organic rice management will provide better soil properties. Stratification of organic carbon and nitrogen was found in top soil from organic and conventional rice fields. Organic rice field appeared to have organic carbon content that was significantly higher than that of conventional rice field, and it is concentrated on top soil surface. The total nitrogen content in layers $0-4 \mathrm{~cm}$ and $4-8 \mathrm{~cm}$ in organic rice field was considerably higher than in conventional, but the content was different in layers $8-24 \mathrm{~cm}$. Nitrate content was significantly different in top soil 12-16, 16-20 and 20-24 cm, significantly in top soil 8-12 cm, with nitrate in top soil of conventional rice field higher than in organic rice field. However, it was not significant in $0-4 \mathrm{~cm}$ and 4-8 $\mathrm{cm}$ top soils. This condition was influenced by organic and synthetic chemical fertilization, nitrification, denitrification and leaching.
\end{abstract}

Keywords: organic carbon; nitrogen; rice field; top soil layer

Cite this as: Anshori, A., Pramono, A., \& Mujiyo. (2020). The Stratification of Organic Carbon and Nitrogen in Top Soils as Affected by the Management of Organic and Conventional Rice Cultivation. Caraka Tani: Journal of Sustainable Agriculture, 35(1), 126-134. doi: http://dx.doi.org/10.20961/carakatani.v35i1.34488

\section{INTRODUCTION}

Rice agricultural intensification increases food production, but decreases the quality of soil, water and biodiversity resources (Pimentel et al., 1995). Organic farming, using manure, compost, crop rotation, without synthetic fertilizers and pesticides, is an alternative to maintain soil fertility and crop production. Organic farming is distinguished in terms of quality (Gąstoł et al., 2011) and higher carbon content (Anshori et al., 2019). Organic farming systems are being explored to improve soil health, agricultural sustainability and environmental quality (Poudel et al., 2002).

Organic farmers tend to apply large amounts of organic fertilizers, so that this prevents environmental degradation such as nitrate pollution (Maeda et al., 2003). Soil organic carbon is associated with better soil quality (Franzluebbers, 2002; Lal, 2004), increases crop productivity (Nusantara et al., 2014), upsurges soil organic carbon stocks (Anshori et al., 2018),

\footnotetext{
* Received for publication September 10, 2019 Accepted after corrections February 21, 2020
} 
significantly promotes sustainable production (Manna et al., 2005) and plays a role in the sustainability of agricultural system (Magdoff and Es, 2009).

Soil organic matter is a major concern in agricultural system. This includes soil biota, plant residues and microorganisms and derived organic products, which are important for soil fertility and ecosystems (Dikgwatlhe et al., 2014). Agricultural management influences soil organic matter (Lal, 2000; Xu et al., 2013). Decomposition of organic matter results in a balance of soil organic matter contents (Korschens et al., 1998).

Soil organic matter pools are created by processing and restoring crop residues (Hou et al., 2012), such rice straw, green manure and farm yard manure to improve soil productivity (Bhatia et al., 2005; Ramesh et al., 2009). The organic matter content varies according to the input of crop residues (Franzluebbers et al., 1998). Organic matter is also a source of nutrients (Bhandari et al., 2002; Magdoff and Es, 2009), including nitrogen (Tarkalson et al., 2009). Carbon and nitrogen are important for the condition of agricultural system (Gao et al., 2007), also $\mathrm{C} / \mathrm{N}$ is important for plant growth (Yang et al., 2011).

The incorporation of organic residues into the soil increases biological activity (Ghosh et al., 2012) and organic carbon (Yagioka et al., 2014) plays a role in soil conservation, compaction and future soil fertility (Wienhold et al., 2013). Organic residue is utilized by soil microorganism and fauna as a source of nutrient and energy for better soil quality (House and Parmelee, 1985; Rasse et al., 2005).

Soil tillage plays a role in the accumulation of soil organic matter (Rasmussen and Collins, 1991; Pendell et al., 2007; Mishra et al., 2009), as well as impacts on the physical and chemical properties of soil (Bai et al., 2009). Conventional tillage increases soil erosion and degradation processes, causes losses in soil organic matter content and promotes the deterioration of the soil quality (Six et al., 1999). The organic matter content varies according to the cultivation system (Burke et al., 1989) and the cropping intensity (Franzluebbers et al., 1998) and includes in the rice cropping (Xu et al., 2013). The content of soil organic matter is different in rice and upland crops (Nishimura et al., 2008).

Depletion of soil organic carbon is a major process of soil degradation (van Noordwijk et al.,
1997) and is largely related to the balance of carbon inputs and outputs. Organic matter may be managed as organic inputs (Nandwa, 2001). The quality and quantity of organic inputs affect the storage of organic matter and soil structure (Droogers and Bouma, 1997). Soil organic matter binds soil particles to form soil aggregates. Stable aggregates provide soil protection (Gupta and Germida, 1988).

Stratification of soil organic carbon at different depths occurring in various ecosystems is function of management practices (Franzluebbers, 2002; Dikgwatlhe et al., 2014; Zhang et al., 2016). The concentration of soil organic matter decreases in depth, and is influenced by tillage (Dikgwatlhe et al., 2014) and planting intensity (Lal, 2000). Soil organic matter decreases exponentially to a depth of $100 \mathrm{~cm}, 30-40 \%$ stored below a depth of $30 \mathrm{~cm}$ (Pan et al., 2008). However, the calculation of data on soil organic matter content usually reaches a depth of $20 \mathrm{~cm}$ to $30 \mathrm{~cm}$ (Schwager and Mikhailova, 2002).

Stratification of soil organic carbon and nitrogen at soil depth is caused by agricultural management practices (Álvarez et al., 2011; Zhao et al., 2015; García et al., 2016). Differences of total nitrogen in the soil depth can be influenced by several things, such as the provision of plant residues (Zhao et al., 2015), land use change (García et al., 2016) and soil tillage (Álvarez et al., 2011).

The content of soil organic matter and nitrogen is determined by the input of crop residues, cropping intensity and cultivation systems. This study aimed to determine the stratification of organic carbon and nitrogen in top soil from organic and conventional rice management.

\section{MATERIALS AND METHOD}

This research was conducted in Jayan Kebonagung Village, Imogiri Sub-district, Bantul Regency, Special Region of Yogyakarta, Indonesia, on the organic and the conventional rice fields, with three replications. The organic and conventional rice field are located at $7^{\circ} 56^{\prime} 01.22^{\prime \prime} \mathrm{N}, 110^{\circ} 22^{\prime} 18.87^{\prime \prime} \mathrm{E}$ and $7^{\circ} 55^{\prime} 57.08 " \mathrm{~N}$, $110^{\circ} 22^{\prime} 17.07$ "E, respectively. The altitude is 60 meters above the sea level. The soil type in this location is classified as Inceptisols. The dose of organic fertilizer in organic rice fields was 10 tons $\mathrm{ha}^{-1}$ season $^{-1}$ and rice stubble was incorporated in the top soil. Organic fertilizer was applied three 
times (before transplanting day, 15 and 30 days after transplanting). The rates of synthetic chemical fertilizers in conventional rice fields were $300 \mathrm{~kg} \mathrm{ha}^{-1}$ season $^{-1}$ of phonska (NPK 15:15:15) and $150 \mathrm{~kg} \mathrm{ha}^{-1}$ season $^{-1}$ of urea (46\% N).

Before rice transplanting was carried out, samples of top soil were taken from organic and conventional rice fields. Soil samples were analyzed for $\mathrm{pH}$ (Eviati and Sulaeman, 2009), texture (Agus et al., 2006a), particle density (Agus and Marwanto, 2006), bulk density (Agus et al., 2006b) and permeability (Dariah et al., 2006).

After rice transplanting, samples of top soil were taken at the depths of $0-4,4-8,8-12,12-16$, $16-20,20-24$ and $24-28 \mathrm{~cm}$ from the organic and conventional rice fields. Soil samples were analyzed for the organic carbon, total nitrogen and nitrate (Eviati and Sulaeman, 2009) to find out the organic carbon and soil nitrogen stratification.

Data were examined statistically. The difference level of organic carbon, total nitrogen and nitrate between organic and conventional rice fields in each layer was determined using the Ttest.

\section{RESULTS AND DISCUSSION}

\section{Rice cultivation}

Organic fertilizer is a source of nutrients for organic agriculture, while conventional agriculture relies on synthetic chemical fertilizers. In research area, the sources of organic fertilizer include compost, weeds and other plants, agricultural waste, agricultural processing waste and non-agricultural organic waste (Anshori et al., 2016). Urea and phonska were used as synthetic chemical fertilizers. The management of organic material and fertilizer can be seen in Table 1.

Table 1. Fertilizers in organic and conventional rice fields

\begin{tabular}{lcc}
\hline \multirow{2}{*}{ Fertilizer } & \multicolumn{2}{c}{ Management of rice fields } \\
\cline { 2 - 3 } & Organic & Conventional \\
\hline Organic & & \\
\hline Rice stubble & Yes & Yes \\
Organic fertilizer & Yes & No \\
\hline Chemical synthetic & & \\
\hline Urea & No & Yes \\
Phonska & No & Yes \\
\hline
\end{tabular}

The control of plant pests in organic rice fields utilized organic materials with the concept of environmental friendly control. Plant pests control in conventional rice fields applied synthetic chemicals. Tillage (hand tractor), planting (2:1 in row) and irrigation with about $2 \mathrm{~cm}$ flooded soil were applied in organic and conventional rice fields.

\section{Characteristics of top soil}

Organic carbon plays a role in soil properties (Sutanto, 2005; Hanafiah, 2012). Soil pH, particle density, bulk density, porosity and permeability in top soils are influenced by rice management. The soil properties of organic and conventional rice management are served on Table 2 .

Table 2. Top soil properties from organic and conventional rice fields

\begin{tabular}{lcc}
\hline \multicolumn{1}{c}{ Soil properties } & $\begin{array}{c}\text { Organic } \\
\text { rice field }\end{array}$ & $\begin{array}{c}\text { Conventional } \\
\text { rice field }\end{array}$ \\
\hline Texture & $\begin{array}{c}\text { Loam } \\
\text { Total organic carbon }\end{array}$ & $\begin{array}{c}\text { Loam } \\
\text { (\%) }\end{array}$ \\
$\mathrm{pH}$ & 6.27 & 1.16 \\
Particle density (g & 1.72 & 6.34 \\
$\left.\mathrm{~cm}^{-3}\right)$ & 1.85 \\
Bulk density $\left(\mathrm{g} \mathrm{cm}^{-3}\right)$ & 1.16 & 1.26 \\
Porosity $(\%)$ & 32.56 & 31.89 \\
Permeability $\left(\mathrm{cm} \mathrm{hr}^{-1}\right)$ & 4.31 & 3.08 \\
\hline
\end{tabular}

Total organic carbon, porosity and permeability in organic rice field were higher than those in conventional rice field, in contrast to particle density and bulk density. This shows that organic rice management leads to better soil properties.

\section{Stratification of organic carbon}

The organic carbon profiles in top soil from organic and conventional rice management during the study are presented in Figure 1. The distribution of organic carbon in top soils varied, influenced by organic fertilization.

The organic and conventional rice management causes a difference in organic carbon content in top soil layers. In all top soil layers, the organic carbon contents of organic and conventional rice fields were significantly different, $0-4 \mathrm{~cm}$ layer $(\mathrm{P}<0.001, \mathrm{n}=3), 4-8 \mathrm{~cm}$ layer $(\mathrm{P}<0.001, \mathrm{n}=3), 8-12 \mathrm{~cm}$ layer $(\mathrm{P}<0.001$, $\mathrm{n}=3), 12-16 \mathrm{~cm}$ layer $(\mathrm{P}<0.001, \mathrm{n}=3), 16-20 \mathrm{~cm}$ layer $(\mathrm{P}<0.001, \mathrm{n}=3)$ and $20-24 \mathrm{~cm}$ layer $(\mathrm{P}<0.005, \mathrm{n}=3)$. The organic carbon at all depths of top soil of organic rice field were significantly higher than the contents in conventional rice field, 
because of the application of organic fertilizer in organic rice management and synthetic chemical fertilizers in conventional rice management. Stratification of soil organic carbon content was also found by Franzluebbers (2002); Pan et al. (2008); Zhang et al. (2016); Mujiyo et al. (2017) and Anshori et al. (2018). Provision of organic fertilizer and plant residues, which are decomposed, produce soil organic carbon residues, causing stratification of organic carbon.

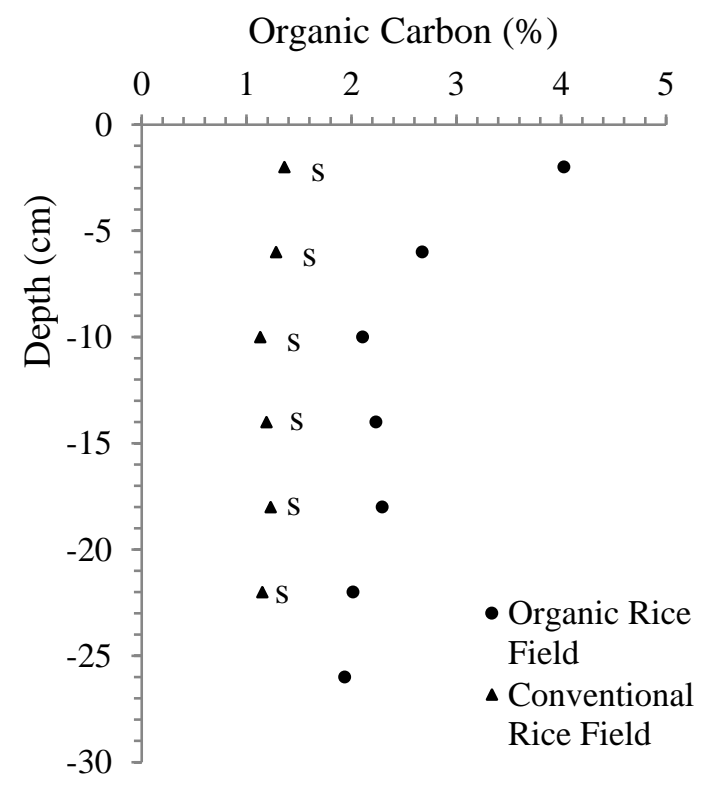

Figure 1. Stratification of organic carbon in top soil of organic and conventional rice fields

Note: The s notations show the significance of soil organic carbon contents in top soil layer of organic and conventional rice fields

The organic carbon contents in conventional rice field were relatively uniform in all layers because of the small input and high intensity of tillage. In organic rice field, the organic carbon contents were high in 0-4 $\mathrm{cm}$ and 4-8 $\mathrm{cm}$ layers because of high organic material input. The application of organic fertilizer using the spread method caused the concentration of organic carbon in top layer soil. Translocation process of organic carbon to the deeper layers was slow and the lack of incorporation into the deeper layer lowered the concentration in the deeper layer. In the depth of $16-20 \mathrm{~cm}$, the soil organic carbon content tended to be high and this might be caused by high density of microorganisms in plant roots, as Mueller et al. (1992). The quantity and/or quality of soil organic matter and its fractions regulate microbial community composition and associated function (Murphy et al., 2011). The results of research by Hou et al. (2012) and Anshori et al. (2018) have shown that the soil organic carbon increased more rapidly in the upper soil layers.

\section{Stratification of nitrogen}

Total nitrogen content was high in soil $0-4 \mathrm{~cm}$ layer. The content in organic rice field was higher because the nitrogen was sourced from organic fertilizer. At the $8-24 \mathrm{~cm}$ depth layer, the total nitrogen content was small, as presented in Figure 2. Total nitrogen was concentrated in the upper layer soil allegedly due to the application of organic fertilizer by the spread method, slow translocation process of organic fertilizer and the lack of top soil incorporation. A similar condition was found by Hou et al. (2012) that in the surface soil layers, at $0-5 \mathrm{~cm}$, total nitrogen increases more rapidly.

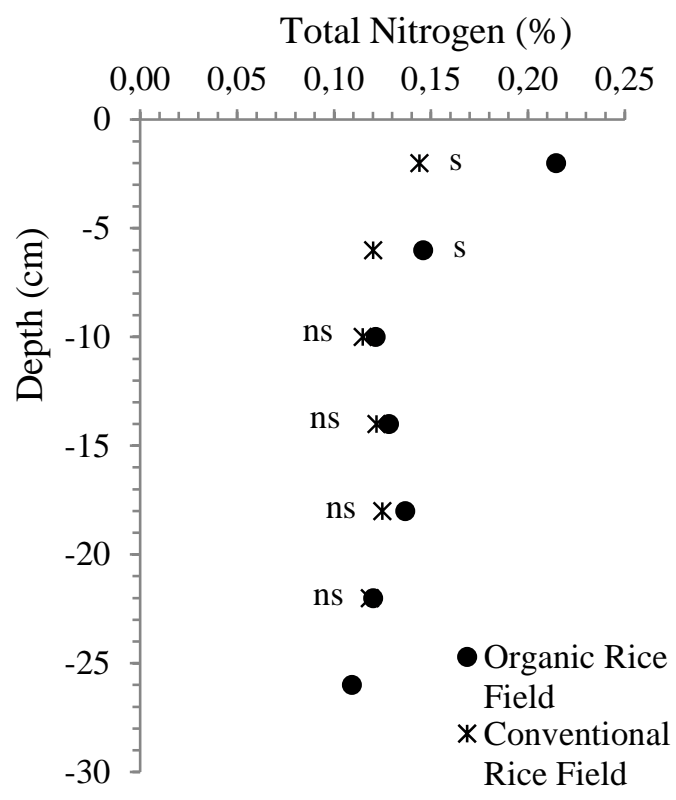

Figure 2. Stratification of total nitrogen in top soil in organic and conventional rice fields

Note: The s notations show the significance, while ns do not show the significance of total nitrogen in top soil layer of organic and conventional rice fields

In $0-4 \mathrm{~cm}$ and $4-8 \mathrm{~cm}$ layer, there were significantly difference in total nitrogen between 
organic and conventional rice fields, with $0-4 \mathrm{~cm}$ layer $(\mathrm{P}<0.01, \mathrm{n}=3)$ and $4-8 \mathrm{~cm}$ layer $(\mathrm{P}<0.01$, $\mathrm{n}=3$ ). However, it were not significant on top soils 8-12, 12-16, 16-20 and 20-24 cm layer. Average total nitrogen in organic rice field was higher than conventional, because the spread of organic fertilizer in organic rice management.

The nitrate content showed the opposite condition (Figure 3). The deeper layer has higher nitrate content. Nitrate stratification in the soil layer was also found by Randall (1990), in line with this results. According to Singh et al. (1995) some of residual nitrogen was leached into the deeper layer. Nitrate leaching is the main route of nitrogen loss (Zhou et al., 2012), so nitrates accumulate in the deeper soil layers.

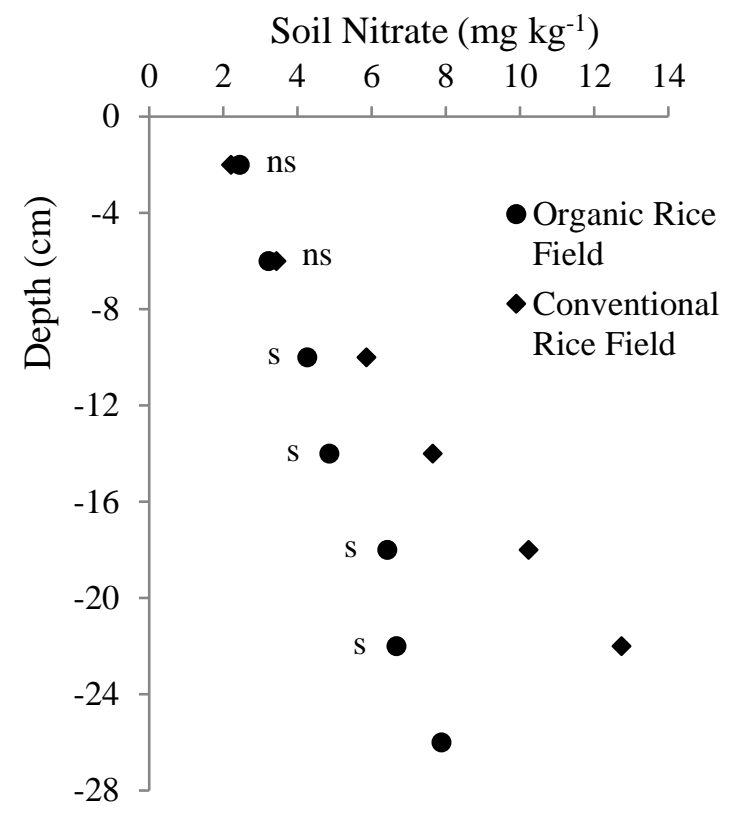

Figure 3. Stratification of soil nitrate in top soil from organic and conventional rice field

Note: The s notations show the significance, while ns do not show the significance of nitrate in top soil layer of organic and conventional rice fields

Nitrate contents were significantly different in $12-16 \mathrm{~cm}$ layer $(\mathrm{P}<0.01, \mathrm{n}=3), 16-20 \mathrm{~cm}$ layer $(\mathrm{P}<0.01, \mathrm{n}=3)$ and $20-24 \mathrm{~cm}$ layer $(\mathrm{P}<0.01, \mathrm{n}=3)$, as well as significantly different in top soil $8-12$ $\mathrm{cm}$ layer, with nitrates in top soil of conventional rice field higher than that in organic rice field. However, the contents were insignificant in both $0-4 \mathrm{~cm}$ and $4-8 \mathrm{~cm}$ layers. Nitrate are commonly leached and concentrated in the deeper layer of soil. Nitrates in conventional rice field were higher than those in organic rice field. This condition was due to the addition of synthetic chemical fertilizers to complement soil nitrate through nitrification reactions. This is line with Cooke et al. (1957) that the concentration of soil nitrate increases with the addition of fertilizer and nitrification reactions. Rice plants absorb N-urea of $20-40 \%$, the rest undergo evaporation, denitrification and leaching (Singh et al., 1995). NPK fertilizer application increases nitrate concentration in the soil (Sunarminto et al., 2014). Nitrogen evaporation was not observed in this research. Furthermore, chemical synthetic fertilizer of nitrogen, organic fertilizer, nitrification, denitrification and leaching affects the nitrate content in the top soil layer and nitrate stratification occurs.

\section{CONCLUSIONS}

Management of both organic and conventional rice fields influences the stratification of organic carbon and nitrogen in the top soil layer. Organic rice field appeared to have higher total organic carbon and nitrogen contents than conventional rice field, and those substances were concentrated on the top soil surface. Nitrate content, on the other hand, was higher in conventional rice field than in organic rice field and was concentrated in the deeper layers.

\section{REFERENCES}

Agus, F., \& Marwanto, S. (2006). Penetapan Berat Jenis Partikel Tanah. In Sifat Fisik Tanah dan Metode Analisisnya. Balai Besar Penelitian dan Pengembangan Sumberdaya Lahan Pertanian. Bogor.

Agus, F., Yusrial, \& Sutono, S. (2006a). Penetapan Tekstur Tanah. In Sifat Fisik Tanah dan Metode Analisisnya. Balai Besar Penelitian dan Pengembangan Sumberdaya Lahan Pertanian. Bogor.

Agus, F., Yustika, R. D., \& Haryati, U. (2006b). Penetapan Berat Volume Tanah. In Sifat Fisik Tanah dan Metode Analisisnya. Balai Besar Penelitian dan Pengembangan Sumberdaya Lahan Pertanian. Bogor.

Álvarez, C. R., Costantini, A. O., Bono, A., Taboada, M. A., Boem, F. H. G., Fernández, P. L. \& Prystupa, P. (2011). Distribution and Vertical Stratification of Carbon and Nitrogen 
in Soil under Different Managements in the Pampean Region of Argentina. Revista Brasileira de Ciência do Solo, 35(6), 19851994. https://doi.org/10.1590/S0100-0683201 1000600015

Anshori, A., Sunarminto, B. H., \& Haryono, E. (2016). Aliran Bahan Organik pada Sawah Padi Organik Dusun Jayan Desa Kebonagung Kec. Imogiri Kab. Bantul. D.I. Yogyakarta. Caraka Tani: Journal of Sustainable Agriculture, 31(1), 45-50. https://doi.org/10. 20961/carakatani.v31i1.11942

Anshori, A., Sunarminto, B. H., Haryono, E. \& Mujiyo, M. (2018). Potential Production of $\mathrm{CH}_{4}$ and $\mathrm{N}_{2} \mathrm{O}$ in Soil Profiles from Organic and Conventional Rice Fields. SAINS TANAH Journal of Soil Science and Agroclimatology, 15(1), 54-60. https://doi.org/10.15608/stjssa. v15i1.19324

Anshori, A., Sunarminto, B. H., Haryono, E., Pramono, A., \& Mujiyo, M. (2019). The Stock and Flowpaths of Organic Carbon in the Irrigated Rice Field from Imogiri Bantul D.I Yogyakarta Indonesia. Proceeding of International Workshop and Seminar: Innovation of Environmental-Friendly Agricultural Technology Supporting Sustainable Food Self-Sufficiency, 318-323. Retieved from http://balingtan.litbang.pertanian.go.id/ind/ind ex.php/publikasi/prosiding-wsi-2018/617-con structed-wetlands-for-wastewater-treatment-i ncluding-those-used-for-fast-growing-timber11

Bai, Y. H., He, J., Li, H. W., Wang, Q. J., Chen, H., Kuhn, H., Chen, F., \& Gong, Y. S. (2009). Soil Structure and Crop Performance after 10 Years of Controlled Traffic and Traditional Tillage Cropping in the Dryland Loess Plateau in China. Soil Science, 174(2), 113-119. https: //doi.org/10.1097/SS.0b013e3181981ddc

Bhandari, A. L., Ladha, J. K., Pathak, H., Padre, A. T., Dawe D., \& Gupta, R. K. (2002). Yield and Soil Nutrient Changes in a Long Term Rice-Wheat Rotation in India. Soil Sci. Soc. Am. J., 66(1), 162-170. https://doi.org/10.2136 /sssaj2002.1620a

Bhatia, A., Pathak, H., Jain, N., Singh, P. K., \& Singh, A. K. (2005). Global Warming Potential of Manure Amended Soils under Rice-Wheat System in the Indo-Gangetic
Plains. Atmospheric Environment, 39(37), 6976-6984. https://doi.org/10.1016/j.atmosen v.2005.07.052

Burke, I. C., Yonker, C. M., Parton, W. J., Cole, C. V., Flach, K., \& Schimel, D. S. (1989). Texture, Climate, and Cultivation Effects on Soil Organic Matter Content in US Grassland Soils. Soil Science Society of America Journal, 53(3), 800-805. https://doi.org/10.2136/sssaj 1989.03615995005300030029x

Cooke, G. W., Bates, J. A. R., \& Tinker, P. B. (1957). Investigations on Soil Nitrogen I. The Influence of Nitrogen Fertilizers and Rainfall on Soil Nitrate Concentrations. Journal of the Science of Food and Agriculture, 8(4), 248252. https://doi.org/10.1002/jsfa.2740080411

Dariah, A., Yusrial, \& Maswar, M. (2006). Penetapan Konduktivitas Hidrolik Tanah dalam Keadaan Jenuh: Metode Laboratorium. In Sifat Fisik Tanah dan Metode Analisisnya. Balai Besar Penelitian dan Pengembangan Sumberdaya Lahan Pertanian. Bogor.

Dikgwatlhe, S. B., Kong, F. L., Chen, Z. D., Lal, R., Zhang, H. L., \& Chen, F. (2014). Tillage and Residue Management Effects on Temporal Changes in Soil Organic Carbon and Fractions of a Silty Loam Soil in the North China Plain. Soil Use and Management, 30(4), 496-506. https://doi.org/10.1111/sum.12143

Droogers, P., \& Bouma, J. (1997). Soil Survey Input in Exploratory Modeling of Sustainable Soil Management Practices. Soil Science Society of America Journal, 61(6), 1704-1710. https://doi.org/10.2136/sssaj1997.036159950 06100060023x

Eviati \& Sulaeman. (2009). Petunjuk Teknis Analisis Tanah, Tanaman, Air dan Pupuk. Balai Penelitian Tanah. Bogor.

Franzluebbers, A. J., Hons, F. M., \& Zuberer., D. A. (1998). In Situ and Potential $\mathrm{CO}_{2}$ Evolution from a Fluventic Ustochrept in Southcentral Texas as affected by Tillage and Cropping Intensity. Soil and Tillage Research, 47(3-4), 303-308. https://doi.org/10.1016/S0167-1987 (98)00118-4

Franzluebbers, A. J. (2002). Soil Organic Matter Stratification Ratio as an Indicator of Soil Quality. Soil and Tillage Research, 66(2), 95- 
106. https://doi.org/10.1016/S0167-1987(02)0 0018-1

Gao, L., Sun, M. H., Liu, X. Z., \& Che, Y. S. (2007). Effects of Carbon Concentration and Carbon to Nitrogen Ratio on the Growth And Sporulation of Several Biocontrol Fungi. Mycological Research, 111(1), 87-92. https:// doi.org/10.1016/j.mycres.2006.07.019

García, B. L., Alcántara, L. P. and Pérez, M. C. (2016). Land Use Change Effects on Stratification and Storage of Soil Carbon and Nitrogen: Application to a Mediterranean Nature Reserve. Agriculture, Ecosystems and Environment, 231, 105-113. https://doi.org/10. 1016/j.agee.2016.06.030

Gąstoł, M., Świątkiewicz, I. D., \& Krośniak, M. (2011). Organic Versus Conventional - a Comparative Study on Quality and Nutritional Value of Fruit and Vegetable Juices. Biological Agriculture \& Horticulture: An International Journal for Sustainable Production Systems, 27(3-4), 310-319. https:// doi.org/10.1080/01448765.2011.648726

Ghosh, S., Wilson, B., Ghoshald, S., Senapatib., N., \& Mandale, B. (2012). Organic Amendments Influence Soil Quality and Carbon Sequestration in the Indo-Gangetic Plains of India. Agriculture, Ecosystems and Environment, 156, 134-141. https://doi.org/10. 1016/j.agee.2012.05.009

Gupta, V. V. S. R. \& Germida, J. J. (1988). Distribution of Microbial Biomass and its Activity in Different Soil Aggregate Size Classes as affected by Cultivation. Soil Biology and Biochemistry, 20(6), 777-786. https://doi.org/10.1016/0038-0717(88)90082$\mathrm{X}$

Hanafiah, K. A. (2012). Dasa-Dasar Ilmu Tanah. PT Raja Grafindo Persada. Jakarta.

Hou, R., Ouyang, Z., Li, Y., Tyler, D. D., Li, F., \& Wilson, G. V. (2012). Effects of Tillage and Residue Management on Soil Organic Carbon and Total Nitrogen in the North China Plain. Soil Science Society of America Journal, 76(1), 230-240. https://doi.org/10.2136/sssaj 2011.0107

House, G. J., \& Parmelee, R. W. (1985). Comparison of Soil Arthropods and Earthworms from Conventional and No-
Tillage Agroecosystems. Soil and Tillage Research, 5(4), 351-360. https://doi.org/10.10 16/S0167-1987(85)80003-9

Korschens, M., Weigel, A., \& Schulz, E. (1998). Turnover of Soil Organic Matter (SOM) and Long-Term Balances - Tools for Evaluating Sustainable Productivity of Soils. Journal of Plant Nutrition and Soil Science, 161(4), 409424. https://doi.org/10.1002/jpln.1998.358161 0409

Lal, R. (2000). World Cropland Soils as a Source or Sink for Atmospheric Carbon. Advances in Agronomy, 71, 145-191. https://doi.org/10.10 16/S0065-2113(01)71014-0

Lal, R. (2004). Soil Carbon Sequestration Impacts on Global Climate Change and Food Security. Science, 304(5677), 1623-1627. https://doi. org/10.1126/science. 1097396

Maeda, M., Zhao, B., Ozakia, Y., \& Yoneyama, T. (2003). Nitrate Leaching in an Andisol Treated with Different Types of Fertilizers. Environmental Pollution, 121(3), 477-487. https://doi.org/10.1016/S0269-7491(02)00233 $-6$

Magdoff, F., \& Es, H. V. (2009). Building Soils for Better Crops: Sustainable Soil Management. Published by the Sustainable Agriculture Research and Education (SARE) program under cooperative agreements with USDA's National Institute of Food and Agriculture, University of Maryland and University of Vermont. Retrieved from https: //www.sare.org/content/download/841/6675/ Building_Soils_For_Better_Crops.pdf?inlined ownload $=1$

Manna, M. C., Swarup, A., Wanjari, R. H., Ravankar, H. N., Mishra, B., Saha, M. N., Singh, Y. V., Sahi, D. K., \& Sarap, P. A. (2005). Long-Term Effect of Fertilizer and Manure Application on Soil Organic Carbon Storage, Soil Quality and Yield Sustainability under Sub-Humid and Semi-Arid Tropical India. Field Crops Research, 93(2-3), 264280. https://doi.org/10.1016/j.fcr.2004.10.006

Mishra, U., Lal, R., Slater, B., Calhoun, F., Liu, D. S., \& Meirvenne, M. V. (2009). Predicting Soil Organic Carbon Stock using Profile Depth Distribution Functions and Ordinary Kriging. Soil Science Society of America Journal, 
73(2), 614-621. https://doi.org/10.2136/sssaj2 007.0410

Mueller, T., Joergensen, R. G., \& Meyer, B. (1992). Estimation of Soil Microbial Biomass $\mathrm{C}$ in the Presence of Living Roots by Fumigation-Extraction. Soil Biology and Biochemistry, 24(2), 179-181. https://doi.org/ 10.1016/0038-0717(92)90275-3

Mujiyo M., Sunarminto, B. H., Hanudin, E., Widada, J., \& Syamsiyah, J. (2017). Methane Production Potential of Soil Profile in Organic Paddy Field. Soil and Water Resources, 4, 212-219. https://doi.org/10.17221/58/2016-S WR

Murphy, D. V., Braimbridge, M., Cookson, W. R. \& Marschner, P. (2011). Relationships between Soil Organic Matter and the Soil Microbial Biomass (Size, Functional Diversity, and Community Structure) in Crop and Pasture Systems in a Semi-Arid Environment. Soil Research, 49(7), 582-594. https://doi.org/10.1071/SR11203

Nandwa, S. M. (2001). Soil Organic Carbon (SOC) Management for Sustainable Productivity of Cropping and Agro-Forestry Systems in Eastern and Southern Africa. Nutrient Cycling in Agroecosystems, 61(1-2), 143-158. https://doi.org/10.1007/978-94-0172172-1_14

Nishimura, S., Yonemura, S., Sawamoto, T., Shirato, Y., Akiyama, H., Sudo, S., \& Yagi, K. (2008). Effect of Land Use Change from Paddy Rice Cultivation to Upland Crop Cultivation on Soil Carbon Budget of a Cropland in Japan. Agriculture, Ecosystems \& Environment, 125(1-4), 9-20. https://doi.org/ 10.1016/j.agee.2007.11.003

Nusantara, C. J., Sumarno, Dewi, W. S., \& Sudadi. (2014). Pengaruh Dosis Inokulum Azolla dan Pupuk Fosfat Alam terhadap Ketersediaan P dan Hasil Padi di Alfisol. Caraka Tani: Journal of Sustainable Agriculture, 29(2), 106-114. https://doi.org/ 10.20961/carakatani.v29i2.13396

Pan, G., Wu., L., Li., L., Zhang, X., Gong, W., \& Wood, Y. (2008). Organic Carbon Stratification and Size Distribution of Three Typical Paddy Soils from Taihu Lake Region, China. Journal of Environmental Sciences, 20(4),
456-463. https://doi.org/10.1016/S1001-0742 (08)62079-3

Pendell, D. L., Williams, J. R., Boyles, S. B., Rice, C. W., \& Nelson, R. G. (2007). Soil Carbon Sequestration Strategies with Alternative Tillage and Nitrogen Sources under Risk. Applied Economic Perspectives and Policy, 29(2), 247-268. https://doi.org/10.1111/j.1467 $-9353.2007 .00341 . x$

Pimentel, D., Harvey, C., Resosudarmo, P., Sinclair, K., Kurz, D., McNair, M., Crist, S., Shpritz, L., Fitton, L., Saffouri, R., \& Blair, R. (1995). Environmental and Economic Costs of Soil Erosion and Conservation Benefits. Science, 267(5201), 1117-1123. https://doi. org/10.1126/science.267.5201.1117

Poudel, D. D., Horwath, W. R., Lanini, W. T., Temple, S. R., \& Bruggen, A. H. C. V. (2002). Comparison of Soil $\mathrm{N}$ Availability and Leaching Potential, Crop Yields and Weeds in Organic, Low-Input and Conventional Farming Systems in Northern California. Agriculture, Ecosystems and Environment, 90(2), 125-137. https://doi.org/10.1016/S0167 -8809(01)00196-7

Ramesh, P., Panwar, N. R., Singh, A. B., Ramana, S., \& Rao, A. S. (2009). Impact of Organic Manure Combinations on the Productivity and Soil Quality in Different Cropping Systems in Central India. Journal of Plant Nutrition and Soil Science, 172(4), 577-585. https://doi.org/ 10.1002/jpln.200700281

Randall, G. W. (1990). Nitrate-N in the Soil Profile and Tile Drainage Water as Influenced by Tillage. American Journal of Industrial Medicine, 18(4), 457-460. https://doi.org/ 10.1002/ajim.4700180417

Rasmussen, P. E., \& Collins, H. P. (1991). LongTerm Impacts of Tillage, Fertilizer, and Crop Residue on Soil Organic Matter in Temperate Semiarid Regions. Advanced Agronomy, 45, 93-134. https://doi.org/10.1016/S0065-2113( 08)60039-5

Rasse, D. P., Rumpel, C., \& Dignac, M. F. (2005). Is Soil Carbon Mostly Root Carbon? Mechanisms for a Specific Stabilization. Plant and Soil, 269(1-2), 341-356. https://doi.org/10. 1007/s11104-004-0907-y

Schwager, S. J., \& Mikhailova, E. A. (2002). 
Estimating Variability in Soil Organic Carbon Storage using the Method of Statistical Differentials. Soil Science, 167(3), 194-200. http://dx.doi.org/10.1097/00010694-2002030 00-00004

Singh, B., Singh, Y., \& Sekhon, G. S. (1995). Fertilizer-N use Efficiency and Nitrate Pollution of Groundwater in Developing Countries. Journal of Contaminant Hydrology, 20(3-4), 167-184. https://doi.org/10.1016/01 69-7722(95)00067-4

Six, J., Elliott, E. T., \& Paustian, K. (1999). Aggregate and Soil Organic Matter Dynamics under Conventional and No-Till Systems. Soil Science Society of America Journal, 63(5), 1350-1358. https://doi.org/10.2136/sssaj1999. 6351350x

Sunarminto, B. H., Nurudin, M., Sulakhudin, \& Wulandari, C. (2014). Peran Geologi dan Mineralogy Tanah untuk Mendukung Teknologi Tepat Guna dalam Pengelolaan Tanah Tropika. Gadjah Mada University Press. Yogyakarta.

Sutanto, R. (2005). Dasar-Dasar Ilmu Tanah: Konsep dan Kenyataan. Penerbit Kanisius. Yogyakarta.

Tarkalson, D. D., Brown, B., Kok, H., \& Bjorneberg, D. (2009). Irrigated Small-Grain Residue Management Effects on Soil Chemical and Physical Properties and Nutrient Cycling. Soil Science, 174(6), 303-311. https: //doi.org/10.1097/SS.0b013e3181a82a5f

van Noordwijk, M., Cerri, C., Woomer, P. L., Nugroho, K., \& Bernoux, M. (1997). Soil Carbon Dynamics in the Humid Forest Zone. Geoderma, 79(1-4), 187-225. https://doi.org/ 10.1016/S0016-7061(97)00042-6

Wienhold, B. J., Varvel, G. E., Johnson, J. M. F., \& Wilhelm, W. W. (2013). Carbon Source Quality and Placement Effects on Soil Organic Carbon Status. BioEnergy Research, 6, 786796. https://doi.org/10.1007/s12155-013-9301
$-\mathrm{Z}$

Xu, S. Q., Zhang, M. Y., Zhang, H. L., Chen, F., Yang, G. L., \& Xiao, X. P. (2013). Soil Organic Carbon Stocks as Affected by Tillage Systems in a Double-Cropped Rice Field. Pedosphere, 23(5), 696-704. https://doi.org/ 10.1016/S1002-0160(13)60062-4

Yagioka, A., Komatsuzaki, M., \& Kaneko, N. (2014). The Effect of Minimum Tillage with Weed Cover Mulching on Organic Daikon (Raphanus sativus var. Longipinnatus cv. Taibyousoufutori) Yield and Quality and on Soil Carbon and Nitrogen Dynamics. Biological Agriculture \& Horticulture, 30(4), 228-242. https://doi.org/10.1080/01448765.20 14.922897

Yang, Y., Luo, Y., \& Finzi, A. C. (2011). Carbon and Nitrogen Dynamics during Forest Stand Development: a Global Synthesis. New Phytologist, 190(4), 977-989. https://doi.org/ 10.1111/j.1469-8137.2011.03645.x

Zhang., Z, Qiang, H., McHugh, A. D., He, J., Li, H., Wang, Q., \& Lu, Z. (2016). Effect of Conservation Farming Practices on Soil Organic Matter and Stratification in a MonoCropping System of Northern China. Soil and Tillage Research, 156, 173-181. https://doi. org/10.1016/j.still.2015.10.008

Zhao, X., Xue, J. F., Zhang, X. Q., Kong, F. L., Chen, F., Lal, R., \& Zhang, H. L. (2015). Stratification and Storage of Soil Organic Carbon and Nitrogen as Affected by Tillage Practices in the North China Plain. PLoS ONE, 10(6), e0128873. https://doi.org/10.1371/jour nal.pone. 0128873

Zhou, M., Zhu, B., Butterbach-Bahl, K., Wang, T., Bergmann, J., Bruggemann, N., Wang, Z., Li, T., \& Kuang, F. (2012). Nitrate Leaching, Direct and Indirect Nitrous Oxide Fluxes from Sloping Cropland in the Purple Soil Area, Southwestern China. Environmental Pollution, 162, 361-368. https://doi.org/10.10 16/j.envpol.2011.12.001 